\title{
Establishment of in vitro regeneration from petiole explants and assessment of clonal fidelity by ISSR markers in Luffa acutangula L.Roxb
}

\author{
Yashodhara Velivela", Muralikrishna Narra, Raghu Ellendula, Srinivas Kota, Sadanandam Abbagani \\ Department of Biotechnology ,Kakatiya University, Warangal, India.
}

\section{ARTICLE INFO \\ Article history: \\ Received on: 08/03/2016 \\ Revised on: 07/04/2016 \\ Accepted on: 18/04/2016 \\ Available online: 21/06/2016}

Key words:

BAP, TDZ, GA 3 , ISSR.

\begin{abstract}
An improved in vitro organogenesis was achieved from petiole explants of Luffa acutangula L. Roxb, a medicinally and economically important cucurbitaceous member. Morphogenetic response of petiole explants excised from in vitro grown plants has been studied with different concentrations of auxins and cytokinins. Higher percent of callus induction was occurred on Murashige and Skoog (MS) medium supplemented with $2 \mathrm{mg} / \mathrm{L}$ BAP and $0.2 \mathrm{mg} / \mathrm{L}$ NAA from the cut ends of petiole explants after 4 weeks of culture. Multiple shoots (8.28 \pm 0.85 shoots per explant) were induced after 2-3 weeks from the green compact callus on MS medium with $30 \mathrm{~g} / \mathrm{L}$ sucrose, $2.0 \mathrm{mg} / \mathrm{L}$ BAP along with $0.2 \mathrm{mg} / \mathrm{L}$ IAA. The elongation of proliferated shoots was achieved on same medium supplemented additionally with $0.3 \mathrm{mg} / \mathrm{L} \mathrm{GA}_{3}$. The elongated shoots $(1 \mathrm{~cm})$ were rooted on MS medium supplemented with $0.5 \mathrm{mg} / \mathrm{L}$ IBA. Rooted plants were acclimatized in the greenhouse and subsequently established in soil with $85 \%$ survival rate. Clonal fidelity of in vitro raised plantlets was determined using ISSR marker technique. The results showed the similar banding pattern with different ISSR primers ranging from $250 \mathrm{bp}$ to $1000 \mathrm{bp}$ and indicated the absence of polymorphism in donar mother plant and as well in in vitro regenerated plants.
\end{abstract}

\section{INTRODUCTION}

The success of in vitro plant regeneration technique in recent years has been standardized and extended to almost every major agronomic, vegetable, medicinal and fiber crop systems and this could be the appropriate approach for maintaining unique source without any genetic change. The plants belonging to cucurbitaceae provide a major portion of vegetable and they need to be investigated further in developing elite transgenic lines for maximum utilization [1]. Luffa acutangula L. Roxb popularly known as ridge gourd and also called angled gourd, belongs to family cucurbitaceae with vital medicinal importance as rich in $\beta$-carotenes, flavonoids, saponins and triterpenes. The entire plant is extensively useful as traditional remedy for anemia, jaundice and in spleen enlargements [2]. It consists of a gelatinous compound called luffein, a ribosomal inactivating protein possessing antiviral properties [3]. Many comprehensive therapeutic advantages of this plant showed analgesic and

\footnotetext{
* Corresponding Author

Yashodhara Velivela, Department of Biotechnology,Kakatiya

University,Warangal, India. Email: yyash69@rediffmail.com
}

antioxidant properties [4].Significant hypoglycemic [5] and hepatoprotective [6] activities of this plant extracts has been studied extensively. In the earlier attempts, successful reports for in vitro regeneration were available from different explants of Luffa acutangula L. Roxb like shoot tip explants [7], cotyledonary nodes, nodal explants [8], internodes [9] and cotyledons [10]. A promising In vitro flowering condition has been employed within this system as a source of viable aseptic anthers for haploid culture [11]. The evaluation of genetic stability of in vitro raised plantlets with molecular markers is consent with clonal identification and analyzing the variations at genetic levels. ISSR (Inter simple sequence repeats) marker system offers a highly discriminative tool in studying genetic fidelity among in vitro cultured plants. Similar consecutive studies with ISSR have been done in cultivar identification in strawberry [12] and also in clonal identification of woodfordia fruticosa [13], Citrullus colocynthis [14]. ISSR markers were used in studying genetic variability in two morphological variants in flower colour with in species of Hyptis suaveolens [15]. In the present investigation, attempts were made to standardize a reproducible protocol for in vitro clonal propagation of petiole explants by organogenesis and assessment of their clonal fidelity using ISSR markers in Luffa acutangula L.Roxb. 


\section{MATERIALS AND METHODS}

\subsection{Explant material}

Seeds of Luffa acutangula L. Roxb were collected from Warangal Seed Company, Telangana. They were washed with running tap water and were decoated.The decoated seeds were surface sterilized with $0.1 \%(\mathrm{~W} / \mathrm{V})$ mercuric chloride for 3-4 minutes, then rinsed with sterile distilled water for 2-3 times to remove traces of sterilant. The seeds were demoistened with sterile filter paper and were cultured onto Murashige and Skoog (MS) [16] medium without hormones. For all experiments, the $\mathrm{P}^{\mathrm{H}}$ of medium was adjusted to 5.6-5.8 and solidified with $0.8 \%$ (W/V) agar. The seeds germinated within a week of culture and subsequently developed into complete plantlets within 3-4 weeks and further experiments were conducted using petiole explants obtained from these well developed plants.

\subsection{Callus initiation and shoot formation}

Explants were cultured on MS medium fortified with various concentrations and combinations of different plant growth regulators for multiple shoot initiation via intervening callus phase. Different concentrations of 6-Benzyl amino purine (BAP) (0.5 mg/L - $3 \mathrm{mg} / \mathrm{L})$, Thiadiazuron (TDZ) $(0.5 \mathrm{mg} / \mathrm{L}-3 \mathrm{mg} / \mathrm{L})$ and 2,4-Dichlorophenoxyacetic acid (2,4-D) $(0.5 \mathrm{mg} / \mathrm{L}-3 \mathrm{mg} / \mathrm{L})$ alone and in combination with $\alpha$-Naphthalene acetic acid (NAA) $(0.1 \mathrm{mg} / \mathrm{L}-0.4 \mathrm{mg} / \mathrm{L})$ were used. Multiple micro shoot buds were initiated from well developed callus after culturing on MS medium supplemented with various concentrations of BAP and IAA within 3-4 weeks with a subculture of 25 days interval onto the same medium.

\subsection{Shoot elongation and Rooting}

Varied concentrations of Gibberellic acid $\left(\mathrm{GA}_{3}\right)(0.1$ $\mathrm{mg} / \mathrm{L}-0.5 \mathrm{mg} / \mathrm{L}$ ) with MS basal medium were used for proper elongation of regenerated shoots. The fully elongated single shoots were excised and transferred to rooting medium containing Indole-3-butyric acid (IBA) at different levels $(0.5 \mathrm{mg} / \mathrm{L}-3$ $\mathrm{mg} / \mathrm{L})$.Fully developed plantlets with complete roots were acclimatized and shifted to greenhouse.

\subsection{PCR conditions}

Total genomic DNA was extracted following a modified cetyl trimethyl ammonium bromide (CTAB) DNA extraction procedure [17] from the leaf tissues of both in vitro raised and in vivo mother plants. Different ISSR primers were tested on the basis of their suitability for detailed study. PCR was performed PCR was performed using $25 \mu \mathrm{L}$ of reaction mixture containing 1 $\mu \mathrm{L}$ ( 0.5 unit per reaction) of Taq DNA polymerase , $2 \mu \mathrm{L}$ of PCR buffer , $1 \mu \mathrm{L}$ of $2.5 \mathrm{mM}$ dNTPs, $1 \mu \mathrm{L}$ of each ISSR primer(10 pmols), $1 \mu \mathrm{L}$ of extracted $\operatorname{DNA}(0.5 \mathrm{ng})$, and $19 \mu \mathrm{L}$ of milliqwater.PCR conditions carried out for amplification consists of an initial denaturation step at $94^{\circ} \mathrm{C}$ for $3 \mathrm{~min}, 40$ cycles of $1 \mathrm{~min}$ at $94^{\circ} \mathrm{C}, 40 \mathrm{sec}$ at $45^{\circ} \mathrm{C}$, and $2.3 \mathrm{~min}$ at $72^{\circ} \mathrm{C}$, followed by final extension of $7 \mathrm{~min}$ at $72^{\circ} \mathrm{C}$, with a soak temperature of $10^{\circ} \mathrm{C}$.

\section{RESULTS AND DISCUSSION}

\subsection{Callusing}

A successful regeneration protocol of ridge gourd was obtained via callus induction from the cut ends of petiole segments in MS medium supplemented with auxin alone or in combination with cytokinin. In this study maximum percentage of callus induction was occurred after 4 weeks of culture and morphological features of callus were found to be different on different medium. The effect of auxins NAA and IAA which can induce callus efficiently on MS medium with BAP showed high frequency of multiple shoot regeneration from Balsam cotyledonary explants [18].However in the present investigation green callusing was observed with BAP in combination with NAA and where as the response in TDZ+NAA $(43.96 \pm 4.38)$ and 2,4-D (43.84 \pm 4.02$)$ alone significantly induced brown, granular to yellowish, compact callus respectively. Green compact callus was formed at a high frequency rate of $81.68 \pm 2.16$ in MS medium containing $2.0 \mathrm{mg} / \mathrm{L}$ BAP with $0.2 \mathrm{mg} / \mathrm{L} \mathrm{NAA}$ and because of their multiplication capability, these calli were used for induction of organogenesis $\{$ Fig.1 a,b $\}$ (Table 1).

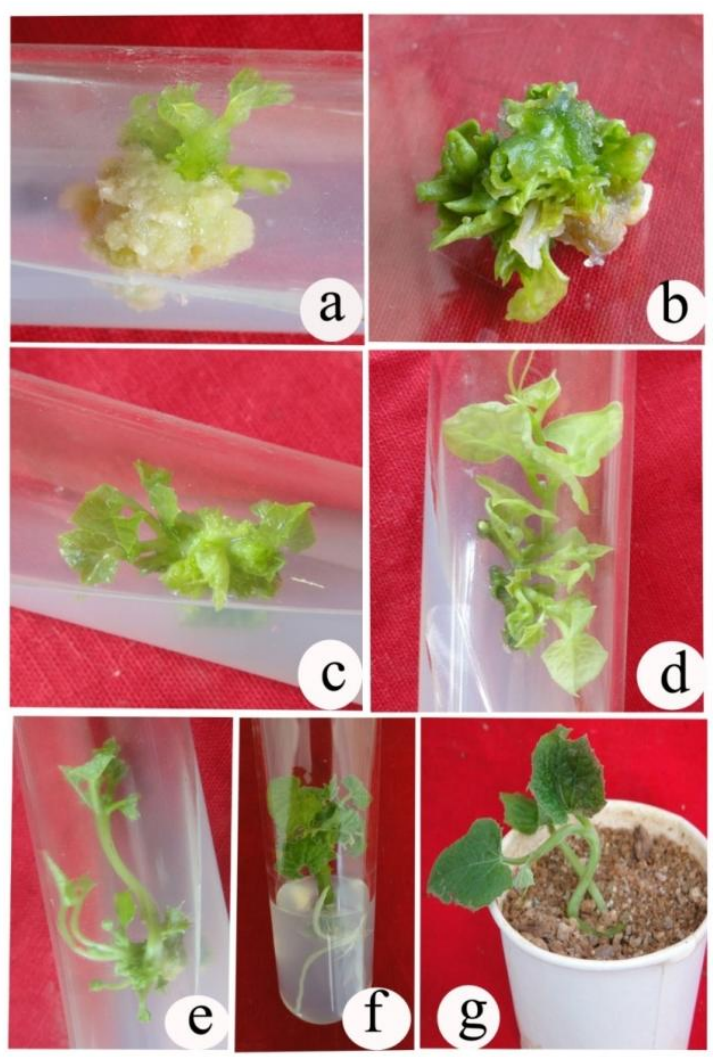

Fig.1: In vitro regeneration from petiole explants of Luffa acutangula L.Roxb. a, b. Initiation of callus derived adventitious shoots. c, d. Proliferation of shoots on MS medium containing $2 \mathrm{mg} / \mathrm{L}$ BAP \& $0.2 \mathrm{mg} / \mathrm{L}$ IAA. e.Elongation of shoots on proliferation medium containing $\mathrm{GA}_{3}(0.3 \mathrm{mg} / \mathrm{L})$. f. Rooting induction in elongated shoots on $0.5 \mathrm{mg} / \mathrm{L}$ IBA. g. Hardened plant in greenhouse

Similar consecutive studies produced organogenic callus in Momordica dioica from different combinations of BAP with NAA and their ratios were intended to play a major role in 
determining the in vitro response from different explants in most cucurbits [19] and further increase in NAA concentrations has showed declining effect on callus proliferation [20].At higher levels, the effect of BAP (42.92 \pm 5.32$)$ and TDZ (28.45 \pm 6.37$)$ was found to show low callogenic response which induced brown, granular callus with different texture and color. whereas callus from $2,4-\mathrm{D}$ is found to be nonorganogenic with a low frequency rate $(43.84 \pm 4.02)$. However the explants failed to show callogenic response on hormonal free MS medium that really explains the importance of varied levels of plant growth regulators that are supplemented to basal medium.

Table 1: Effect of various concentrations of Hormones on callus induction from petiole explants of Luffa acutangula L.Roxb.

\begin{tabular}{|c|c|c|}
\hline $\begin{array}{l}\text { Hormones } \\
(\mathrm{mg} / \mathrm{L})\end{array}$ & \% Response & $\begin{array}{c}\text { Morphological feature of } \\
\text { callus } \\
\end{array}$ \\
\hline \multicolumn{3}{|l|}{ 2,4-D } \\
\hline 0.5 & $27.68 \pm 5.21$ & Yellowish- brown granular \\
\hline 1.0 & $36.68 \pm 6.23$ & Yellowish, compact \\
\hline 2.0 & $41.44 \pm 5.58$ & Brown, Granular \\
\hline 3.0 & $43.84 \pm 4.02$ & Brown, Granular \\
\hline \multicolumn{3}{|l|}{$\mathbf{B A P}$ + NAA } \\
\hline $0.5+0.2$ & $42.92 \pm 5.32$ & Yellowish, Nodular \\
\hline $1.0+0.2$ & $63.28 \pm 6.19$ & Green, compact \\
\hline $2.0+0.2$ & $81.68 \pm 2.16$ & Green, compact \\
\hline $3.0+0.2$ & $42.92 \pm 5.32$ & Brown, Granular \\
\hline \multicolumn{3}{|l|}{ TDZ + NAA } \\
\hline $0.5+0.2$ & $54.08 \pm 7.09$ & Yellowish - brown compact \\
\hline $1.0+0.2$ & $43.96 \pm 4.38$ & Yellowish brown Nodular \\
\hline $2.0+0.2$ & $39.76 \pm 5.80$ & Brown, Granular \\
\hline $3.0+0.2$ & $28.45 \pm 6.37$ & Brown, Granular \\
\hline
\end{tabular}

Values are given as Mean \pm standard error (SE) represents the $\%$ of response of 25 replicates per treatment and the data was recorded after 4-weeks of culture.

\subsection{Multiple shoots initiation}

The combination of cytokinins with auxins play a key role in promoting the induction of multiple shoots and among the various hormonal supplements used, the best shootbud differentiating response was observed from green compact callus on MS medium with $2 \mathrm{mg} / \mathrm{L}$ BAP in combination with $0.2 \mathrm{mg} / \mathrm{L}$ IAA. In this, an average of $8.28 \pm 0.85$ shoots with a frequency percent of $83.2 \pm 7.90$ per explants was observed. Phytohormone TDZ $1 \mathrm{mg} / \mathrm{L}$ with $0.2 \mathrm{mg} / \mathrm{L}$ IAA showed response in initiating $4.48 \pm 0.48$ shoots per explant with $54.8 \pm 7.20$ frequency whereas increased concentrations of both the hormones gave a diminishing effect on shoot multiplication $\{$ Fig.1c,d\}(Table 2). Manye et al. studied that, the type of callus used for further proliferation of shoots and appropriate proportionate quantity of phytohormones play a key role in establishing the in vitro cultures by differentiating the callus and initiating the multiple shoots in Momordica charantia L [21]. The Individual hormonal levels of BAP and TDZ at $1 \mathrm{mg} / \mathrm{L}$ alone has exhibited shooting response at an average of $2.44 \pm 0.63$ and $3.36 \pm 0.60$ shoots respectively and at lower frequency rate when compared to their combination with IAA. Comparatively the same findings were achieved on low shooting response when single hormonal medium is used for rapid in vitro studies [22].
Table 2: Induction of Multiple shoot buds on various hormonal concentrations of BAP and TDZ alone and in combination with IAA from petiole explants of Luffa acutangula L.Roxb.

\begin{tabular}{ccc}
\hline $\begin{array}{c}\text { Hormones } \\
(\mathbf{m g} / \mathbf{L})\end{array}$ & $\begin{array}{c}\text { \% callus induced } \\
\text { shoots }\end{array}$ & $\begin{array}{c}\text { No. of Shoots/Explant } \\
(\text { Mean } \pm \mathbf{S . E})\end{array}$ \\
\hline 0.5 & $31.4 \pm 8.01$ & $2.32 \pm 0.61$ \\
1.0 & $38.8 \pm 8.47$ & $2.44 \pm 0.63$ \\
2.0 & $31.8 \pm 8.34$ & $1.92 \pm 0.52$ \\
3.0 & $29.4 \pm 5.48$ & $1.36 \pm 0.37$ \\
\hline BAP + IAA & & \\
$0.5+0.2$ & $18.4 \pm 6.87$ & $2.12 \pm 0.38$ \\
$1.0+0.2$ & $32.2 \pm 7.54$ & $2.96 \pm 0.66$ \\
$2.0+0.2$ & $83.2 \pm 7.90$ & $8.28 \pm 0.85$ \\
$3.0+0.2$ & $26.2 \pm 6.34$ & $1.68 \pm 0.45$ \\
\hline TDZ & & $1.84 \pm 0.42$ \\
0.5 & $15.4 \pm 4.33$ & $3.36 \pm 0.60$ \\
1.0 & $20.8 \pm 6.87$ & $2.76 \pm 0.76$ \\
2.0 & $28.8 \pm 7.79$ & $2.12 \pm 0.38$ \\
3.0 & $19.2 \pm 7.53$ & \\
TDZ + IAA & & $2.72 \pm 0.80$ \\
$0.5+0.2$ & $12.5 \pm 3.12$ & $4.48 \pm 0.48$ \\
$1.0+0.2$ & $54.8 \pm 7.20$ & $2.52 \pm 0.53$ \\
$2.0+0.2$ & $27.4 \pm 6.54$ & $1.88 \pm 0.45$ \\
$3.0+0.2$ & $16.2 \pm 3.85$ & 159
\end{tabular}

Values are given as Mean \pm standard error (SE) represents the No.of Shoots/Explant of 25 replicates per treatment and the data was recorded after 34weeks of culture.

\subsection{Shoot elongation and Rooting}

In this study, satisfactory results were obtained with BAP and found to be more effective when compared to TDZ. The proliferated shoots that were transferred to same regeneration medium containing $\mathrm{GA}_{3}(0.3 \mathrm{mg} / \mathrm{L})$ showed shoot elongation of $3.12 \pm 0.50 \mathrm{~cm}$ with $85 \%$ response \{Fig.1e\}(Table 3) and these results support the findings in Cucumis sativus and Cucurbita pepo by selvaraj et al. and Ananthakrishnan et al [23,24] respectively. Best rooting response of these elongated shoots were observed after 2 weeks of culture when transferred to MS medium supplemented with $0.5 \mathrm{mg} / \mathrm{L}$ IBA with an average number of 11 roots per explants $\{$ Fig.1f $\}$. In contrast, other auxins like NAA and IAA have been found to be effective in inducing roots in other plant systems like Momordica charantia [25] and however here in case of Luffa acutangula, there is poor rooting response in terms of inducing low number, weak and roots were found to be slender with NAA and IAA (data not shown). The rooted plants were gently washed and transferred to plastic container containing sterile soil and vermiculite mixture in 1:1 ratio and maintained in greenhouse for 2 weeks of hardening with a survival rate of $85 \%$ \{Fig.1g\}. The morphological features of hardened plantlets were found to be quite similar to that of parental lines.

Table 3: Effect of $\mathrm{GA}_{3}$ on elongation of proliferated shoots from petiole explants of Luffa acutangula L. Roxb cultured on MS medium containing BAP $(2.0 \mathrm{mg} / \mathrm{L})+(0.2 \mathrm{mg} / \mathrm{L})$ IAA.

\begin{tabular}{ccc}
\hline $\mathbf{G A 3}(\mathbf{m g} / \mathbf{L})$ & \% response & Shoot Length $(\mathbf{c m})$ \\
\hline 0.1 & 43 & $1.36 \pm 0.26$ \\
0.2 & 73 & $2.28 \pm 0.74$ \\
0.3 & 85 & $3.12 \pm 0.50$ \\
\hline
\end{tabular}

Each treatment consisted of 25 replicates and repeated thrice.

\subsection{Clonal fidelity}

Clonal fidelity is one of the essential consideration to determine the level of genetic similarity between regenerants and 
their mother plant that are raised by in vitro tissue culture methods [26] and where there could be a chance of inducing somaclonal variation in micropropagated plants [27]. Molecular markers are the precise tools that are used rapidly to determine and reveal genetic differences from in vitro raised plants and non tissue culture derived controls. Here in this report, the assessment of genetic stability between in vitro regenerated plants in comparison to a single donor mother plant was carried out using ISSR fingerprinting and this could be reliable in determining variability at DNA level in plants and some of similar findings has been established in other plants [28] and also because of their simplicity and cost effectiveness this method has been adopted for the present study.
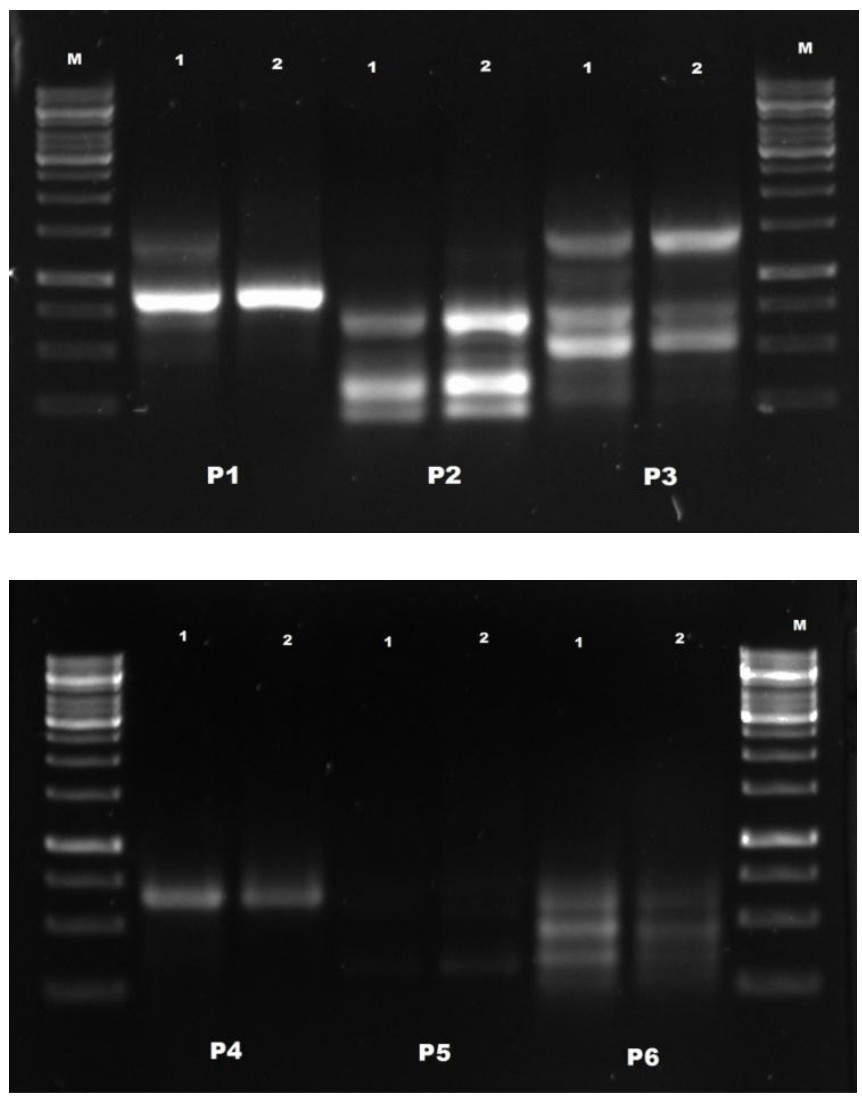

Fig. 2: Assessment of clonal fidelity in in vitro regenerants by ISSR markers M-Marker, 1-Mother donar plant, 2-In vitro regenerated plant,P1,P2,P3,P4,P5,P6-Primers used for amplification

Out of 7 ISSR primers screened, 6 primers developed distinct and scorable bands with a size ranging from $250 \mathrm{bp}$ to 1000 bp \{Fig. 2a,b\} (Table 4). All the bands displayed monomorphic patterns. Thus ISSR marker system has revealed the genetic stability in in vitro regenerants with almost indicating complete uniformity. The present results are similar with various reports that have been summarized on rapid regeneration protocols from different explant sources and absence of genetic variability amongst in vitro raised and donar plant systems like Asparagus officinalis [29], Chlorophytum arundinaceum Baker [30] and Momordica charantia L [31].
Table 4: List of ISSR primers used for analyzing genetic stability in micropropagated plants of Luffa acutangula L.Roxb.

\begin{tabular}{cll}
\hline $\begin{array}{c}\text { ISSR } \\
\text { marker No. }\end{array}$ & \multicolumn{1}{c}{ Primer Sequence (5'-3') } & \multicolumn{1}{c}{ Size Range (bp) } \\
\hline P1 & AGAGAGAGAGAGAGAGG & $750-900 \mathrm{bp}$ \\
P2 & GAGAGAGAGAGAGAGAC & $250-750 \mathrm{bp}$ \\
P3 & TCTCTCTCTCTCTCTCG & $500-1500 \mathrm{bp}$ \\
P4 & AGAGAGAGAGAGAGAGYT & $500-750 \mathrm{bp}$ \\
P5 & TCTCTCTCTCTCTCTCC & $250-500 \mathrm{bp}$ \\
P6 & AGAGAGAGAGAGAGAGG & $250-1000 \mathrm{bp}$ \\
P7 & GAGAGAGAGAGAGAGAT & No amplification \\
\hline
\end{tabular}

\section{CONCLUSION}

The present investigation has demonstrated a simple regeneration protocol for conservation and multiplication through callus derived shoot organogenesis from petiole segments of Luffa acutangula L. Roxb and this can be applied for transgenic improvement in this species. The use of BAP and TDZ in combination with IAA or NAA favoured plant regeneration and callus induction respectively and this is the first report confirming the clonal fidelity of regenerated plants with ISSR markers.

\section{ACKNOWLEDGEMENTS}

Dr. Yashodhara is greatly thankful to University Grants Commission (UGC) for financial support under UGC-women post doctoral programme (F.15-24/12(SA-II)).

\section{REFERENCES}

1. Halder T, Gadgil VN. Morphogenesis in some species of the family cucurbitaceae. Tissue Culture of Economic Important Plants. In: A.N. Rao (ed.), 1982; 98-103.

2. Badgujar SB, Patil MB. Estimation of the chemical constituents of L. acutangula Var. amara. (Roxb). Natural Product Radiance. 2008; 7(1): 79-81.

3. Au TK, Collins RA, Lam TL, Ng TB, Fong WP, Wan DC. The plant ribosome inactivating proteins luffin and saponin are potent inhibitors of HIV-1 integrase. FEBS letters. 2000; 471 (2-3): 169-172.

4. Naresh Singh Gill, Rashmi Arora, Shiv Ranjan Kumar. Evaluation of Antioxidant, Anti-inflammatory and Analgesic potential of the Luffa acutangula Roxb.var. amara. Research Journal of Phytochemistry. 2011; 5(4):202-208.

5. Jusal P, Quanico, Evangeline C, Amor, Grace G, Perez. Analgesic and Hypoglycemic activities of Bixa orellana, Kyllinga monocephala and Luffa acutangula. Philippine Journal of Science. 2008; 137(1): 69-76.

6. Jadhav VB, Thakare VN, Suralkar AA, Despane AD, Naik SR Hepatoprotective activity of Luffa acutangula against CCI4 and rifampicin induced liver toxicity in rats: a biochemical and histopathological evaluation. Indian Journal of Experimental Biology. 2010; 48(8): 822-829.

7. Nahar E, Haque ME, Sikdar B. Comparison of the effects of growth regulators on in vitro regeneration of ridge gourd and sponge gourd through shoot. J.bio.Sci. 2010; 18:88-93.

8. Roly ZY, Mahmudul M, Haque ME, Islam MA, Sikdar B. In vitro multiple shoot regeneration from cotyledonary nodes, shoot tips and nodal segments of ridge gourd. J Discovery Biotech. 2013; 4(9):4-8.

9. Syed Moideen R, Lakshmi Prabha A. In Vitro Plant regeneration of Luffa acutangula Roxb. Var amara Lin.: An Important Medicinal Plant. International Journal of Science and Research. 2015; 4(5):117122.

10. Umamaheswari C, Ambethkar A, Shantha MF, Selvaraj N. In vitro multiple shoot regeneration from cotyledon explants of Luffa 
acutangula (L.) Roxb. International Journal of Current Biotechnology. 2014; 2(7):7-13.

11. Partha Sarathi Saha, Biswajit Ghosh. Micropropagation and in Vitro Flowering of Luffa acutangula (L.) Roxb.- an Important Vegetable Crop. International Journal of Bio-resource and Stress Management. 2014; 5(1):012-021.

12. Arnau G, Lallemand J, Bourgoin M. Fast and reliable strawberry cultivar identification using inter simple sequence repeat (ISSR) amplification.Euphytica. 2003; 129(1):69-79.

13. Mallesham B, Srinivas K, Deepa R, Mahender A,Venugopal Rao K, Kranthi Kumar G, Sadanandam A. An Efficient in vitro Leaf-based Regeneration and Evaluation of Genetic Fidelity Using ISSR Markers in Woodfordia fruticosa (L.) Kurz. Journal of Herbs, Spices \& Medicinal Plants. 2012; 18:178-190.

14. Ramakrishna D, Muralikrishna N, Raghu E, Srinivas K, Shasthree T. Efficient in vitro propagation system via multiple shoot induction and assessment of clonal fidelity of regenerants in Citrullus colocynthis (1.) Schard. Plant Cell Biotechnology and Molecular Biology. 2015; 16(3\&4):108-118

15. Kranthi kumar G, Murthy N.E, Nataraj P, Srinivas K, Prasad Babu A, Teixeira da Silva JA, Raju VS, Sadanandam A. ISSR Markers Reveal Genetic Polymorphism in Two Morphological Variants of Hyptis suaveolens Invasive to India. Medicinal and Aromatic Plant Science and Biotechnology. 2011; 5 (2):166-168.

16. Murashige T, Skoog FA. A revised medium for rapid growth and bioassays with tobacco tissue cultures. Physiol Plant. 1962; 15:473497.

17. Doyle JJ, Doyle JL. A rapid DNA isolation procedure from small quantities of fresh leaf tissues. Phytochem Bull. 1987; 19:11-15.

18. Taha A, Wagiran A, Ghazali H, Huyop F, Parvez GKA. In vitro regeneration of Garden balsam, Impatiens baslamina using cotyledons derived seedlings. Biotechnology. 2009; 8(1):44-52.

19. Nabi SA, Rashid MM, Al-Amin M., Rasul MG. Organogenesis in Teasle Gourd. (Momordica dioica Roxb.).Plant Tiss Cult. 2002; 12(2):173-180.

20. Malik S, Zia M, Rehman R, Chaudhary F. In vitro plant regeneration from direct and indirect organogenesis of Momordica charantia L. Pak J Biol Sci. 2007; 10:4118-4122.

21. Manye Y, Maojun Z, Yu Z, Liqong L, Fang C. Establishment of in vitro regeneration system of Bitter Melon (Momordica charantia L.). High Technol Lett. 2004; 10:44-48.

22. Pierik RLM. In vitro propagation of higher plants. 1987; Martinus Nizhoof Publisher, Boston.

23. Selvaraj N, Vasudevan A, Manickavasagam M, Ganapathi A. In vitro organogenesis and plant formation in cucumber. Biol Plant. 2006b; $50: 123-126$
24. Ananthakrishnan G, Xia X, Elman C, Singer S, Paris HS, Gal-On A, Gaba V. Shoot production in squash (Cucurbita pepo) by in vitro organogenesis. Plant Cell Rep. 2003; 21:739-746.

25. Islam R, Sarkar PK, Naderuzzaman ATM, Joarder OI. In vitro regeneration of plants from cotyledons of Momordica charantia L. Plant Tissue Cult. 1994; 4:105-109.

26. Giri CC, Shyamkumar B, Anjaneyulu C. Progress in tissue culture genetic transformation and application of biotechnology to tress: an overview.Trees.2004; 18:115-135.

27. Larkin PJ, Scowcroft WR. Somaclonal variation-a novel source of variability from cell cultures for plant improvement. Theor. Appl.Genet.1981; 60:197-214.

28. Kumar N, Modi AR, Singh AS, Gajera BB, Patel AR, Patel MP, Subhash N. Assessment of genetic fidelity of micropropagated date palm (phoenix dactylifera L.) plants by RAPD \& ISSR markers assay. Physiol Mol Biol Plants. 2010a; 16:207-213.

29. Raimondi JP, Camadro EL, Masuelli RW. Assessment of somaclonal variation in Asparagus by RAPD fingerprinting and cytogenetic analyses. Sci Hortic. 2001; 90:19-29.

30. Latto SK, Bamotra S, Saprudhar R, Khan S, Dhar AK. Rapid plant regeneration and analysis of genetic fidelity of in vitro derived plants of Chlorophytum arundinaceum Baker-an endangered medicinal herb. Plant Cell Rep. 2006; 25:499-506.

31. Yashodhara V, Muralikrishna N, Raghu E, Bharathkumar K, Rathnaprabha D, Sadanandam A. in vitro plant regeneration from petiole explants and assessment of genetic fidelity using ISSR markers in momordica charantia L. Plant Cell Biotechnology and Molecular Biology. 2016; 17(1\&2):49-56.

\section{How to cite this article:}

Velivela $Y$, Narra $M$, Ellendula $R$, Kota $S$, Abbagani $S$. Establishment of In vitro regeneration from petiole explants and assessment of clonal fidelity by ISSR markers in Luffa acutangula L.Roxb. J App Biol Biotech. 2016; 4 (03): 041-045. DOI: 10.7324/JABB.2016.40307 